答 青木（演者） $10 \mathrm{bit}$

買問 花山（大阪大) (1) CCD カメラの維持管理は (2) ハレーション防止用フィルタは必要か

答 青木 (演者) (1) CCD 素子自体は経年変化がないの で不要。光学系を含めると従来通りの管理は必要.

江口 (演者) (2) ブルーミングに強いため，その分だ けハレーションに強くなってはいるが，良い画像を得る にはフィルタが必要と思う。

質問 座長 残像がないので量子ノイズは増えないか

答、永井 (演者) リカーシブおよび空間フィル夕の組 合わせの適正化により対処しており問題ない.

質問 座長 既設システムにCCD カメラの取付けは 可能加

答 青木 (演者) 光学系，カメラ，プロセッサーを含 めて全て交換すれば可能。

\section{DR-9 DSA・撮影手技他（演題番号438～441）}

\section{三和秋雄（大分医科大学附属病院）}

本セッションでは, DSA 撮影およびその関連技術につ いて，4 題の研究発表がなされた。

演題番号438，本演題は，DSA にお污濃度補償に関 する発表である.DSA 撮影時の濃度補償フィルターにつ いての報告は，その方法・形状・材質等についてこれま でも数多くなされているが, 本演題は，吸収体で被写体 部位を覆うことにより，その被写体厚を均一化し，これ によりハレーションを防止する法（発表では，被写体厚 均一法と称している。)を考案し，その材質およびその適 応部位等について検討を加えたものである.

演者らは, この被写体厚均一法に用いる補償フィルタ 一材としては，被写体形状に良く密着することや均一な 濃度分布が得られること，検査部位の固定にも供する等 の理由により，超音波検查用ソノゼリーが最も優れてお り，また臨床的には，特に四肢 DSA 撮影に有用であると した.

しかしながら，このソノゼリー使用による被写体厚均 一法も，すべての部位に適用可能というものでもなく， 体幹部については依然として，これまでの(セラミック) 粘土フィルター法等が，濃度補償の均一性扝よび作業効 率の点で優れているようであり，結局は，目的部位に応 じた使い分け，あるいは両者の併用という方法を取らざ るを得ないようである。

質問：高村（越谷市立病院）四肢については，その大 きさや被写体厚にかなりの個人差あると思うが，濃度補 償用ゼリーの量は，どの用に変化させて使用しているの
か。また，ビニール袋に封入して使用しているようであ るが, 形状等は任意に変化させることが可能か.

答 現在：ゼリ一の量がそれぞれ $1,3,5 \mathrm{~kg}$ のもの を用意し，被写体厚により適宜選択して使用している. 形状は，任意に変化させることができる．濃度補償物質 としてゼリ一状物質に着目した理由はそこにある。

質問 座長 ソノゼリーを封入しているナイロン袋の 耐久性およびソノゼリー自体の価格に問題はないか。

答 ナイロン袋は，市販のやや薄手のものを使用して いるので，その耐久性についてはやや問題があるかも知 れない：しかし，逆に強度があまりに強すぎる場合，被 写体との密着が不十分となる可能性が出てくる.どちら を優先すべきかとなると,やはり密着性を重視すべきと 考える．今回は，薄手のものを重权て用いている，洒格 にういては，指摘の通りであるので，今後さらに安価で しかも容易に入手可能なものを検討して行きたい.

演題番号439. IVR 手技に扔ける DSA 撮影は，その対 象症例のほとんどが, CT・MR 等の非侵襲的検査によ り，その病巣部位・形態等が予め把握されているため, 必ずしも大口径 I.I. 使用による広範囲の撮影を行なう必 要はないとして, 演者らの施設では, 小口径 I.I. と付属の 多重絞りの活用を行ない, 必要部位のみをスポット撮影 しているという。また，デジタル装置に取り込む映像信 号レベルを従来よりも低くすることにより，結果的にそ のダイナミックレンジを広くする方法（これについては， 本学会でもすでに報告されている.）の併用により，ハレ ーショシ防止のための補償フィルター等の使用も不要と なり, DSA 撮影の簡素化を実現していると述べこれら により検査時間の短縮とテスト曝射回数の減少による被 曝線量の低減等が可能になったと報告した。しかしなが ら，DSA 撮影は，演者の施設のように，その適用が常に IVRに限定されるわけでもないし，またすべてが小口径 I.I. によるスポット撮影にて対処できるわけでもない, 犬口径 I.I. 使用による，いわゆるコンベンショナルな DSA 撮影についてはどう対処すべきか.これらについて の検討を期待したい.

質問 座長 今学会でも幾つかの CCD カメラに関す る報告がなされている。このCCD カメラの場合, ブルー ミング等が大幅に改善されるため，ハレーションの防止 には極めて有用と考えるが，これらについて検討はされ たか.

答 検討していない.

演題番号 440 本演題は, 画質向上の陰にやや黙殺され て来た感のある,DSA 撮影時の被曝線量の低減を目的と 
した研究発表である. 具体的には, X線量/フレームを従 来の500 $\mu \mathrm{R}$ より $200 \mu \mathrm{R}$ にで減少させ,一方では, その 使用造影刘濃度をこれまでの1.5倍に濃縮して投与する というものであるが，この場合，X線量の大幅な低減に より生じると考学られるシステム全体の S/N の低下は, 若干の CRT ウインド処理により相殺され, その画像の 粒状性・血管識別能等も臨床上何ら問題になることはな く, しかも本法は, 頭部および心臓領域以外のす心゙てに 適用可能だという。

本研究発表の注目点は，線量を従来の半分以下にして いるにもかかわらず，単に造影剤濃度を上昇させること のみで，これまでと同等の画像が常に得られるのかどう かという点と考える. 会場より質問もなされたが, 大血 管のみならず各血管分枝・毛細血管・静脈等についても 同様の臨床評価が得られるのか. 今回の検討は，512 マ トリクスにての検討だが $1024^{2}$ マトリクスでも同様の傾 向を示すのか.さらに, 被曝線量低減のための解決策を 使用造影剂量に求めているとも理解できるが, 臨床医サ イドの全面的なコンセンサスが得られるのか. また智床 例も今のところそれほど多くない等, 本演題にはいくつ かの疑問点, 問題点が依然として存在する様に感じられ るが，冒頭にも述べたごとく医療被曝が注目される昨今， 本法は大変に與味深い試みであるので, 今後さらに研究 を継続していく意義は十分にあると考える。

質問，加藤（香川医大）供覧された症例はすべて動脈 相の画像であったが，静脈相（特に，腫汮濃染像や門脈 等) についても, 本法にて, 従来と同等の画像が得られ るのか。

答これまでに経験した範囲では，ほほ同等との詿価 を得ているが，さらに多くの症例について検討を加えて 行きたい.

演題番号441 DSA 画像の辺縁部の画質が，その中心 部に比べて劣ることは以前より知られている。本演題は, これらを実証すべく両者間のコントラスト分解能・鮮鋭 度招よび粒状性等について視覚的・物理的な評価を行な ったものである。測定結果は，ほ涩予想された通りのレ ベルであうたが, DSA 撮影に従事する者(特に, 大口径 I.I. 使用時）は，これらを良く理解しておく必要があろ う.なお今回の比較・評価は，システムの最終段階であ る CRTフィルム上，つまりシステム全体としての評価 であるため, 構成コンポーネントそれぞれの影響が全く クリアーにされていない.

演者が指摘するように，X線管の方向・ターゲット角 度および I.I.の性能等に起因するX線量・発光量の差異
等による影響が大きなウエートを占めていることは理解 できるが, 今後さらにシステム構成コンポーネント個々 の問題について検討を加えて行く必要があろう。

質問 座長 最近のデジタル画像処理技術の進歩はま ことに目賞ましいが：これらの最新技術の応用により， 今回指摘された問題の一部が，クリアーされる可能性は ないか.

答 朝比奈 (東芝) 確かに血管像のコントラストの改 善を目的とした, 散乱線補正処理・幾何学的ヒズミの補 正等，種々の試みがなされているが，今回の発表の中に もあったような画像周辺部での幾何学的不鮮鋭の補正等 は, 現状ではかなり難しい.

\section{核医学機器- 2（演題番号442～445）}

\section{松平正道（金沢大学医学部附属病院）}

本セッションはJIS 規格に関する演題とガンマカメ ラの quality controlあるいは性能に関する基礎的なテ ーマの発表であった。演題442および443は JIS-Z-4992 (単光子放出体断層装置用ファントーム) すなわち SPECT 用ファントーム規格の改正に伴い, このファン トームの特に内容器の基礎データを得るため行なった実 験結果が発表された.SPECT 装置の進歩に伴う JIS 規 格の改正であるが，千葉ガンセンタの木下から，このフ アントームをューザが使用して SPECT 性能をテストす る場合, 度々の改正による規格変更で新たに購入するこ とは費用の面からも負担が大きいということ．改正の必 要性等についても意見が述べられた.これらのことに関 連してファントームの技術的内容や実験結果について, さらに堀りさげて討論すべきことがあったと考えられた が，時間的制約でその余裕がなかったことが残念であっ た。

演題 444 は 2 核種同時収集やマルチピーク $\left({ }^{67} \mathrm{Gn} の 3\right.$ ピーク等).収集時の各エネルギーウィンドウ毎の画像ズ レの有無をテストする方法について述べられたこの発 表では 2 個のエネルギーウィンドウによる点線源の画像 間のサブトラクション法を用いる新たな方法が提案され た.この方法はテストが容易で画像ズレを視覚的に観察 することができ，有用な方法であると思われる。

演題445は小動物のポジトロン核種イメージを得る目 的でシングルヘッド型ガンマカメラとピンホールコリメ ータによる万法が検討されていた．ピンホールコリトー 夕の遮へい能力を高め, その性能評価を行っていた。岩 手医大の長岡より，ピンホールコリメータの遮へい能力 を高めるための方法について質問があり，また堀井（所 